\title{
Mercury Distribution and Methylmercury Mobility in the Sediments of Three Sites on the Lebanese Coast, Eastern Mediterranean
}

\author{
Carine Abi-Ghanem ${ }^{1,{ }^{*}}$, Khaled Nakhlé ${ }^{1}$, Gaby Khalaf ${ }^{1}$ and Daniel Cossa ${ }^{2}$ \\ ${ }^{1}$ Centre National des Sciences Marines, CNRSL, PO Box 534, Batroun, Lebanon \\ 2 Ifremer, LBCM, Centre de Méditerranée, BP 330, 83507 La Seyne sur mer, France \\ *: Corresponding author : Carine Abi-Ghanem, Tel.: 009613831286 ; Fax : 009616741584 ; \\ email address : carine.a.ghanem@hotmail.fr
}

\begin{abstract}
:
Mercury $(\mathrm{Hg})$ contamination in coastal sediments has been widely studied in clay deposits; however, equivalent results on carbonated sediments are scarce. This article aims to study $\mathrm{Hg}$ distribution in Lebanese carbonate coastal marine sediments (Eastern Mediterranean) in order to characterize their contamination level and to explore the postdepositional mobility of methylmercury $(\mathrm{MeHg})$ in the deposits. Vertical distribution profiles of total $(\mathrm{HgT})$ and $\mathrm{MeHg}$ have been established for the solid phase of sediment cores collected in various near-shore environments chosen for their hypothetical various degrees of anthropization. In addition, dissolved $\mathrm{MeHg}$ was determined in sediment pore waters to test its mobility and potential availability for biota. Three sites on the Lebanese coastsAkkar, Dora, and Selaata-were selected. Akkar is far from any direct contamination source, whereas Dora, located near the Beirut harbor, is a heavily urbanized and industrialized zone including a huge dump site, and Selaata is near a chemical plant that produces phosphate fertilizers. Particulate HgT concentrations in the sediments varied between $<0.04$ and $0.65 \mu \mathrm{g} / \mathrm{g}$, with a proportion of $\mathrm{MeHg}$ lower than $1 \%$. Based on a sediment quality guideline (MacDonald et al. 2000), we concluded that Dora bay sediments are heavily contaminated by $\mathrm{Hg}$, with concentrations exceeding the "consensus-based threshold effect" level $(0.17 \mu \mathrm{g} / \mathrm{g})$ and almost reaching the "effects range-medium" level $(0.71 \mu \mathrm{g} / \mathrm{g})$. In spite of the low HgT concentration in Akkar and Selaata sediment (similar to natural carbonated sediment: $0.04 \mu \mathrm{g} / \mathrm{g}$ according to Turekian and Wedephol (1961), a closer analysis of the sediment core vertical profile allows one to observe an anthropogenic impact. This impact might be toxicologically insignificant; however, it allows tracing the time increase of $\mathrm{Hg}$ diffuse deposition. On the other hand, dissolved $\mathrm{MeHg}$ concentrations ranged from 0.04 to 0.09 and from 0.04 to $8.76 \mathrm{ng} / \mathrm{l}$ in the Selaata and the Dora sediments, respectively; MeHg vertical profiles in interstitial water enabled us to calculate diffusive fluxes of $\mathrm{MeHg}$ from the sediment varying from 0.3 to $1.0 \mathrm{ng} / \mathrm{m}^{2} / \mathrm{day}$. Thus, the deposited sediments constitute a measurable source of bioavailable $\mathrm{Hg}$ for epibenthic organisms.
\end{abstract}




\section{Introduction}

Mercury is a highly toxic metal, which, because of its volatility, can be rapidly spread all over the world from its natural and anthropogenic sources. These properties combined with its huge biomagnification in the food chain, make it the metal of the most environmental concern (e.g., Morel et al. 1998; Fitzgerald et al. 2007). The anthropogenic mercury sources are both diffuse and local. The diffuse sources are mainly the burning of fossil fuel, especially coal, the incineration of municipal solid waste, and the cement production; the local sources consist mainly of effluents from industrial activities, especially in developing countries (Sanchez Uria and Sanz-Mendel 1998; Pirrone et al. 2001).

Around the Mediterranean basin the anthropogenic mercury emissions have been estimated to be $106 \times 10^{3} \mathrm{~kg} \mathrm{yr}^{-1}$, i.e., one third of the total European emissions (Pirrone et al. 2001). Other studies from the same research group concluded that the Mediterranean Sea region is not only affected by mercury released in its vicinity but also from air masses enriched in mercury from regions of northern and northeastern Europe (Pirrone et al. 2003). In addition, from a public health point of view, special interest concerning mercury has been focused on the Mediterranean area since decades when high concentrations of total mercury $(\mathrm{HgT})$, mainly as methylmercury $(\mathrm{MeHg})$, were found in Mediterranean fish (e.g., Bernhard and Renzoni 1977; Baldi et al. 1983). The question of the origin of the $\mathrm{MeHg}$ thus arose since the $\mathrm{Hg}$ deposition is thought to be mainly inorganic species. Albeit the recent evidence for mercury methylation in the Mediterranean water column (Cossa et al. 2009), the importance of off-shore sediments as a source of MeHg has even been estimated (Ogrinc et al. 2007) and could be significant at least for benthic communities. For coastal sediments, while $\mathrm{HgT}$ distribution and $\mathrm{MeHg}$ mobility studies in western part of the Mediterranean are now more than a few (e.g., Corvelli et al. 1999; Muresan et al. 2007), equivalent results on the Eastern coasts are still rare. Moreover, Eastern Mediterranean sediments are particular since they are characterized by high carbonate content (e.g., Morse 2003), a chemical matrix poorly explored in term of mercury distribution and transformations. For the Lebanese coastal area Nassif (2004) measured $\mathrm{Hg}$ concentrations up to $0.46 \mathrm{\mu g} \mathrm{g}^{-1}$ (dry weight) in marine sediments collected north of Beirut, a level which exceeds sediment quality guidelines, such as the one developed for the US Status and Trends Program (1999) and the French Geode Program (2000), which have been fixed at 0.17 and $0.4 \mu^{-1} \mathrm{~g}^{-1}$ (dry weight) respectively. In addition, for such contaminated sediments, the key process determining the risk is the net transformation of inorganic $\mathrm{Hg}$ to the highly toxic and bioavailable MeHg (Skyllberg et al. 2007).

We present here the vertical distributions of $\mathrm{HgT}$ and $\mathrm{MeHg}$ in sediment cores collected at three sites on the Lebanese coast (Eastern Mediterranean), in both solid phase and interstitial waters in order to explore the burial, transformations and post-depositional mobility of this element. This should provide information about the anthropogenic impregnation of these coastal sediments and their role in providing $\mathrm{MeHg}$ species for the surrounding seawaters. This mercury speciation study is completed by ancillary data to characterize the sedimentary context (mineralogy and major elements composition).

\section{Material and methods}

\subsection{Study area}

The Lebanese coastal zone, which constitutes one part of the carbonate platform that covers most of the Eastern Mediterranean basin, is the geological result of the carbonated marine sedimentation between the Jurassic and the Quaternary periods (Abdel-Rahman and Nader 2002). 
Geological surveys indicate the presence of thick layers of dolomite, marls or chalk. These carbonate rocks are the only ones that reach today's littoral. Volcanic rocks also exist in two different layers in the stratigraphic sequence. The volcanic complexes (basalts and ashes) of the Jurassic cover a low surface and are exposed to the level of the deep valleys of Mount-Lebanon. The volcanic rocks (mainly basaltic) from the Quaternary Miocene age cover a large surface of the Akkar plate (Sanlaville 1977).

The prospected zone is the coastal area located between Tripoli and the Syrian boundary in the North and Beirut in the South (Fig. 1). This zone has been selected for its relatively high urban and industrial activities; it contains more than $30 \%$ of Lebanese industries and more than $40 \%$ of the population of Lebanon (Nakhlé 2003). For our study three sites representative of the Lebanese coast were selected because they include urban, industrial, and, apparently non-contaminated zone. Three bays were studied: from North to South: Akkar, Selaata, and Dora. Akkar was chosen because the site is located opposite the seemingly non-contaminated bay of Akkar, far from any great industrial activity or urbanization. The site of Selaata, North of the city of Batroun, is near a chemical plant (established in 1957), which produces phosphoric acid, triple superphosphate, aluminum sulfate and sulfuric acid (Al-Hajj and Muscat 2000) and discharges phosphogypsum effluents into the sea through a pipe. Dora is a heavily urbanized and industrialized zone of the St George bay, adjacent to the Beirut harbor, characterized by a dumpsite peninsula that received $12010^{6} \mathrm{~kg}$ of industrial and municipal waste per year until 1998, the year of its closure (CDR/ECODIT-IAURIF 1997). In addition, the St Georges bay receives the inputs from the drainage area of the Beirut River $\left(0.1-10 \mathrm{~m}^{3} \mathrm{~s}^{-1}\right)$, where are located various industries including tanneries (Nakhlé, 2003).

\subsection{Sampling methods}

Sediment cores for the solid phase collection were taken from the three sites Akkar ( $A$ and $A^{\prime}$ ), Dora (D and, D') and Selaata (S1, S3, S4 and S6) by divers during two periods. The number of cores collected was higher at Selaata than in the two other locations because we wanted to trace there the possible contamination gradient from the mouth of the effluent pipe seaward. In February 2006, A', D' and S1 sediment cores were collected in order to analyze $\mathrm{HgT}$ and particulate MeHg in the solid fraction of the sediment. In October and November 2006, sediment cores were collected at A, D, S3, S4, S6 for $\mathrm{HgT}$ analyses and to determine additional mineralogical, datation, major elements and organic carbon (Table 1). For this purpose, acid pre-washed metacrylate tubes (40 cm long and with an inner diameter of $7 \mathrm{~cm}$ ) were vertically introduced into the sediment, plugged on both sides with plastic caps, and brought back to the boat, where they were maintained in a vertical position in a refrigerated box until returning to the laboratory. In the second sediment sampling campaign, in addition to Akkar (A) and Dora (D) sediment cores, three cores were sampled at Selaata sediments S3, S6 and S4, the first one facing the chemical power plant and in direct contact with its effluent, the second located in a bay to the north of the Selaata plant, relatively protected from marine currents, where higher amounts of fine sediment were expected to be present. A supplementary S4 core, located between S3 and S6, was also collected for mineralogical analysis. In the laboratory, the sediment cores were sliced at 1-cm intervals for the first $5 \mathrm{~cm}$ and at $3-\mathrm{cm}$ intervals to the bottom of the core. Subsamples were put into polyethylene bags and frozen at $-18^{\circ} \mathrm{C}$.

Sediment pore waters collected in October 2007 at Dora and Selaata using multi-chambered in situ dialysis samplers (peepers) proposed by Hesslein (1976). This method is based on the equilibration of a contained quantity of deionizied water with the surrounding interstitial water of the sediment through a dialysis membrane. The sampler (peeper) is composed of a metacrylate body with 40 wells drilled into it every two centimeters. These wells were covered by a polycarbonate membrane $(0.45 \mu \mathrm{m})$ and filled with deionized water Milli-Q ${ }^{\circledR}$ (Millipore). Two peepers were vertically introduced by divers into the sediment at the three sites, keeping 6 to 8 wells above the 
sediment water interface to examine differences between overlying and pore water $\mathrm{MeHg}$ concentrations. These peepers were maintained in the sediment for 2 weeks. However, due to sea storm we were only able to recover two peepers at Dora ( $D$ and $\left.D^{\prime}\right)$ and one from the sediment of Selaata (S6). Upon removal, interstitial waters in different compartments were extracted, using syringes, and stored in Teflon (FEP) tubes, as previously described. All the plastic ware used for collecting pore waters was acid washed and Milli-Q ${ }^{\circledR}$ (Millipore) rinsed before use.

\subsection{Analyses}

Prior to the analyses, the sliced frozen sediments were air-dried in an oven at $50^{\circ} \mathrm{C}$ until reaching constant weight, with frequent manual agitation in order to avoid their cementation. Then, the sediment slices were dry sieved $(<63 \mu \mathrm{m})$ using an acid pre-cleaned nylon sieve, the fraction $(<63$ $\mu \mathrm{m})$, stored in polyethylene vials, being used for further analysis. Major elements of sediment were measured to assess their relationship with $\mathrm{HgT}$ and $\mathrm{MeHg}$ distribution. The concentrations of $\mathrm{Ca}$, $\mathrm{Si}$ and $\mathrm{Mg}$ were determined using an inductively coupled plasma mass spectrometer, and the concentrations of Fe and Al by atomic absorption spectrophotometry. The detailed analytical procedures are given in the companion paper concerning the $\mathrm{Pb}$ contamination of the same sediments (Abi-Ghanem et al., 2009).

\subsection{1 $\mathrm{HgT}$ and $\mathrm{MeHg}$ analysis in the solid fraction of the sediment}

HgT analyses were carried out on a semi-automatic system AMA-254® produced by ALTEC (Czech Republic). Aliquots of sediments were weighed and put into an Ni capsule and were automatically introduced into the system, where they were exposed to high temperature $\left(550^{\circ} \mathrm{C}\right)$, so that the mercury is volatilized and carried on by an oxygen current. Then elemental mercury is concentrated by amalgamation on a golden trap before being thermally dissociated and analysed by atomic absorption spectrometry.

The method detection limit was $0.007 \mu \mathrm{g} \mathrm{g}^{-1}$ calculated as 3.29 times the standard deviation of the blank. The reproducibility was $1.8 \%$ for material whose $\mathrm{HgT}$ concentration was $0.092 \mu \mathrm{g} \mathrm{g}^{-1}$. Certified reference material MESS-2 was also used to assure the quality control of the method, and the values obtained $(0.092 \pm 0.002)$ were always within the range of the certified values $0.092 \pm$ $0.009 \mu \mathrm{g} \mathrm{g}^{-1}$. Statistical calculations were performed on the basis of six replicate analyses.

Particulate $\mathrm{MeHg}$ analyses were conducted on the finer than $63 \mu \mathrm{m}$ sediment fraction of Akkar, Dora and Selaata after propylation and isotopic dilution, and a detection by gas chromatography inductively coupled plasma mass spectrometry (GC-ICPMS). This method was slightly modified from Monperrus et al. (2005). A known quantity of $\mathrm{Me}^{202} \mathrm{Hg}$ was added to the sediments, $\mathrm{MeHg}$ extracted using $\mathrm{HNO}_{3}\left(6 \mathrm{M}\right.$, Merck, Suprapur $\left.{ }^{\circledR}\right)$ and propylated by the use of $100 \mu \mathrm{L}$ sodium tetrapropylborate $4 \%$ (Galab). The propylated $\mathrm{MeHg}$ extracted into iso-octane $(0.3 \mathrm{~mL}$ iso-octane $1300 \mathrm{mg}$ sediments) and the detection was carried out by GC-ICPMS (GC-Focuswith X-series; Thermo Electron). The ratio of the surface areas of peaks corresponding to $\mathrm{Me}^{200} \mathrm{Hg}$ and $\mathrm{Me}^{202} \mathrm{Hg}$ makes it possible to calculate the original concentration of $\mathrm{MeHg}$ in the sediments. The detection limit for the $\mathrm{MeHg}$ method was $0.02 \mathrm{ng} \mathrm{g}^{-1}$ and the precision was $20 \%$ for concentrations higher than $1 \mathrm{ng} \mathrm{g}^{-1}$ and $30 \%$ for the lower values. The accuracy of the $\mathrm{MeHg}$ analysis was established using Certified Reference Material IAEA-405. The average concentration for IAEA-405 was $5.49 \pm$ $0.4 \mathrm{ng} \mathrm{g}^{-1}$ compared to the certified value of $5.49 \pm 0.3 \mathrm{ng} \mathrm{g}^{-1}$. 


\subsubsection{Dissolved MeHg analysis}

Dissolved methylmercury $\left(\mathrm{MeHg}_{\mathrm{D}}\right)$ contained in interstitial water collected from Dora and Selaata sediments was analyzed with a technique combining hydruration and cryogenic chromatography. The protocol applied is suggested by Tseng et al. (1998) and modified by Cossa et al. (2003). It is based on the use of $\mathrm{NaBH}_{4}$ to transform $\mathrm{MeHg}$ into volatile $\mathrm{MeHgH}$, however $\mathrm{Hg}^{2+}$ is also transformed into volatile $\mathrm{HgH}_{2}$ and $\mathrm{Hg}^{0}$ within this reaction. These volatile compounds are then concentrated by a cryogenic procedure $\left(-196^{\circ} \mathrm{C}\right)$ on a column filled with Chromosorb W/AWDMCS (60/80 mesh impregnated with $15 \%$ OV-3) in a nitrogen bath before being progressively released by heating the column from $-196^{\circ} \mathrm{C}$ to $90^{\circ} \mathrm{C}$. These compounds are thermally decomposed into $\mathrm{Hg}^{0}$ within a furnace $\left(800^{\circ} \mathrm{C}\right)$, then transported in a vapor state by a current of helium (35 $\mathrm{ml} / \mathrm{min})$ to an atomic fluorescence spectrophotometer (AFS). The blank of the method was checked regularly and was often close to the picogram level for MeHg. The absence of certified reference material for marine interstitial water samples didn't enable us to verify the accuracy of the method. The reproductibility of the method, as described above, varies from $15 \%$ for samples with a concentration near the limit of detection, to $6 \%$ for samples with a $0.1 \mathrm{ng} \mathrm{L}^{-1}$ $\mathrm{MeHg}$ concentration or more (Cossa et al. 2003). The field of linearity ranged from the limit of detection (0.02 $\mathrm{ng} \mathrm{L}^{-1}$ for a $10 \mathrm{~mL}$ sample) to $20 \mathrm{ng} \mathrm{L}^{-1}$.

\section{Result and discussion}

\subsection{Sediment characteristics}

Mineralogical analyses and sediment dating have already been published in a companion paper (Abi-Ghanem et al., 2009). Briefly, the results showed a high contribution of dolomite, calcite and quartz at the three sites. Ankerite and fluorite were more specific of Akkar and Selaata sediments respectively. The ${ }^{210} \mathrm{~Pb}_{\mathrm{ex}}$ and ${ }^{137} \mathrm{Cs}$ measurements suggested that Akkar (A) and Dora (D) are mainly composed of detritic sediments from the coastal erosion (or anthropogenic quarry material) with very little influence of biogenic marine origin and recent continental alluvial deposits. At Selaata ${ }^{210} \mathrm{~Pb}_{\mathrm{ex}}$ measurements do not exhibit any linear decrease with depth. This suggests that the origin of the ${ }^{210} \mathrm{~Pb}_{\mathrm{ex}}$ is to be found in the waste from the Selaata phosphoric acid plant (AbiGhanem et al., 2009).

The major element composition of the sediment is summarized by a ternary plot (Fig. 2) in which three different sample groups are to be distinguished, corresponding to the sediments of Akkar (A), Dora (D) and Selaata (S6 and S3). Akkar sediments are the most highly enriched in $\mathrm{CaCO}_{3}$ and $\mathrm{MgCO}_{3}(70-80 \%)$, while the Dora sediments show the highest content in $\mathrm{SiO}_{2}(45-60 \%)$. The Selaata sediments show levels between those of the Akkar and Dora sediments. It is important to note that the contribution of $\mathrm{Fe}$ and $\mathrm{Al}$, is similar for the three groups of sediment, with mass percentages, expressed as $\mathrm{Fe}_{2} \mathrm{O}_{3}+\mathrm{Al}_{2} \mathrm{O}_{3}$, ranging from 5 to $15 \%$. It may be concluded that the chemical composition of the sediments is consistent with the mineralogical results. Vertical profiles of $\mathrm{Ca}, \mathrm{Mg}, \mathrm{Si}, \mathrm{Fe}$ and Al in Akkar (A), Dora (D) and Selaata (S3 and S6) sediments are discussed in detail in another paper (Abi-Ghanem et al., 2009).

\subsection{Total mercury distributions}

Total mercury ( $\mathrm{HgT}$ ) concentration profiles are presented in figure 3 for Akkar (Fig. 3a), Dora (see Fig. 3b) and Selaata (see Fig. 3c). Since natural variations of $\mathrm{Hg}$ concentrations in sediments can result from differences in the grain size, the mineralogy, and the redox of the sediment, we tried to limit these sources of variability by applying the grain-size normalization approach, completed by a 
geochemical correction; this treatment should allow better insight into the anthropogenic influence on the $\mathrm{Hg}$ distribution in the sediment cores. Thus, $\mathrm{HgT}$ concentrations were determined in the sediment fraction $(<63 \mu \mathrm{m})$ according to Ackermann et al. (1983) and were geochemically normalized by the use of a tracer element (Kersten and Smedes 2002) for total mercury concentrations at A, D, S3 and S6 sediment cores. In addition, Al was chosen as a normalizer element to take into account the clay mineral indicator capacity of the sediment.

\subsubsection{Akkar (see Fig. 3a)}

The HgT concentrations varied from 0.012 to $0.035 \mu \mathrm{g} \mathrm{g}^{-1}$ in core A and from 0.009 to $0.027 \mu g \mathrm{~g}^{-1}$ in core $A^{\prime}$. These concentrations are within the range of the earth crust values and comparable to mercury concentrations in sandstone and carbonate rocks $\left(0.03\right.$ and $0.04 \mu \mathrm{g} \mathrm{g}^{-1}$ respectively according to Turekian and Wedephol (1961) and in some uncontaminated sediment from the Eastern Mediterranean coasts (Table 2). They are also comparable to values detected in deep-sea Mediterranean sediment (Cossa and Coquery 2005). Compared to the 'background' level of coastal Sicilian sediments $0.038 \mu \mathrm{g} \mathrm{g}^{-1}$ calculated by Di Leonardo et al. (2006) and which are chemically and mineralogically close to the Lebanese sediments, the deepest levels of Akkar sediments have a much lower mercury concentration and, thus, it would be reasonable to consider the very low mercury concentration observed at the deepest level $(28 \mathrm{~cm})$, as the mercury background of this coastal zone. However, while $\mathrm{HgT}$ concentration levels in Akkar sediments suggest that the $\mathrm{Hg}$ anthropogenic inputs are quite insignificant, the vertical profile of $\mathrm{HgT}$ concentrations clearly shows regular concentration increase from the bottom of the core up to 10 $\mathrm{cm}$ below the surface (see Fig. 3a), the origin of which should be explained. To question the importance of anthropogenic influence we adopted the approach described by Covelli et al. (2001), who used the comparison of $\mathrm{Hg}$ and other trace metals enrichment factors (EF). The EF of an element is the ratio between the potential enriched concentration of the element and the baseline, which is the background value of the element, these later concentrations being normalized to a conservative element. The above metal concentrations are normalized to Al and are subdivided to the baseline, which is the concentration of the element that corresponds to the deepest layer, and which is also normalized to Al. This method applied by Covelli et al. (2001) helps to obtain a nondimensional enrichment factor (EF):

$$
E F=(M / N) \text { sample/(M/N) baseline, }
$$

$M$ is the concentration of the potentially enriched element, while $N$ is the concentration of the normalising element. Fig. 4 shows the Hg EF distributions, varying up to 4, obtained from Akkar (A) sediment core. Even if this enrichment is small compared to a heavily impacted area such as the Trieste Gulf (24 fold according the Covelli et al. 2001), we address the question as to the anthropogenic influence on the 4 fold variation encountered. Hg EF presented vertical profiles similar to those obtained for $\mathrm{Pb}$ (see Fig. 4), which suggests similar sources for the two metals. Lead sources in these sediments were determined by stable isotopic analyses presented in another paper (Abi-Ghanem et al. 2009). We showed that, based on the ${ }^{206} \mathrm{~Pb} /{ }^{207} \mathrm{~Pb}$ values, the $\mathrm{Pb}$ at the $28 \mathrm{~cm}$ level naturally originates from Miocene silicate rocks, while in the upper sediment levels the contribution of industrial and gasoline lead was detected. Thus, we can infer from these results that mercury and lead EF variations respond to similar histories of human impact. Indeed, Pirrone et al. (2001) estimated that $1.510^{3} \mathrm{~kg}$ of anthropogenic mercury per year are emitted in the atmosphere of Lebanon, coming from fossil fuel combustion, the incineration of municipal solid waste, cement production and other miscellaneous minor sources. Anthropogenic mercury emitted into the atmosphere can be transferred to terrestrial and water receptors by dry deposition, wet scavenging followed by precipitation and by gaseous mercury exchange at the air-water interface. It may be concluded that, even if the $\mathrm{HgT}$ concentrations in the solid phase of the sediment from Akkar are quite low compared to many coastal environments, the current influence of diffuse 
anthropogenic mercury via the atmosphere can be clearly detected. The current anthropic contribution appears to be of at least a similar magnitude as that of the natural contribution. Unfortunately, the ${ }^{210} \mathrm{~Pb}$ and ${ }^{137} \mathrm{Cs}$ data obtained from this core do not permit the determination of the period when the anthropization began.

\subsubsection{Dora (see Fig. 3b)}

High HgT concentrations typical of a contaminated environment (see Table 2) were detected at Dora D and D' sediment cores where mercury concentrations fluctuate from 0.37 to 0.65 and from 0.1 to $0.5 \mu \mathrm{g} \mathrm{g}^{-1}$, respectively (see Fig. 3b). These high mercury concentrations are, especially that Dora's marine water column is contaminated with mercury $\left(7-8 \mathrm{ng} \mathrm{L}^{-1}\right.$ ) (Nakhlé 2003). Mercury can reach Dora Bay in several ways, by: (i) atmospheric inputs, (ii) the huge dumpsite nearby, which is in direct contact with marine water and (iii) through Beirut and the Antélias rivers, where several sources of untreated urban waste waters are discharged. Data concerning dissolved and particulate mercury in the Antélias River have shown concentrations reaching $3.1 \mathrm{ng} \mathrm{\textrm {L } ^ { - 1 }}$ and $2.1 \mathrm{ng}$ $\mathrm{g}^{-1}$ respectively (Nakhlé 2003). These values are higher than values corresponding to other Lebanese rivers and are comparable to values detected in some other polluted rivers in the world. In spite of the differences in the concentrations, both Dora HgT profiles, D and D', present three major peaks, at approximately 4, 10 and $23 \mathrm{~cm}$ depth (see Fig. 3b). In addition, the persistence of elevated mercury concentrations even at the deepest layers of the sediment cores indicates that we did not reach the background levels at Dora sediments. Normalizing mercury to Al in Dora D sediment core allows the smoothing out of the Hg fluctuations, but at least two peaks persist, while the mineralogy does not change significantly with depth (Abi-Ghanem et al. 2009). These changes are most likely related to the varying sources of wastes discharged nearby during the activity of the Dora dumpsite (1980-1998). Clearly the Dora Bay is heavily contaminated by mercury. Sedimentary mercury mobility and potential bioavailability will be further clarified thanks to $\mathrm{MeHg}$ analysis in the solid phase and in the interstitial water of the sediments (see sections 3.3 and 3.4).

\subsubsection{Selaata (see Fig. 3c)}

At Selaata HgT concentrations varied from 0.02 to $0.06 \mu \mathrm{g} \mathrm{g}{ }^{-1}$. These concentrations are comparable to values obtained by Nassif (2004) in Selaata sediments and are in most of the sediment layers superior to values detected in other Lebanese sediments (Akkar-Batroun) (see Table 2). Thus, in spite of the fact that these concentration levels are of lower orders of magnitude than the mercury concentration in contaminated areas (see Table 2), we cannot dismiss the fact that mercury enrichment occurs in some sediment layers, all the more so since $\mathrm{Hg}$ enriched phosphogypsum deposits are present (METAP/Tebodin 1998; Jackson et al. 1986). Fig. 3c illustrates the HgT variation in the two Selaata cores (S3 and S6). At S3, facing the Selaata chemical plant effluent and in direct contact with the phosphogypsum discharged, the mercury profile is characterized by a two layer distribution, the rupture zone being located between 6 and 8 $\mathrm{cm}$, the superficial $6 \mathrm{~cm}$ layers of the S3 core being the most highly enriched in mercury $(0.059 \mu \mathrm{g}$ $\mathrm{g}^{-1}$ ). Normalizing mercury to Al in the S3 core (Fig. 3c) does not eliminate the two layer-structure. This two-layer structure has also been observed by Fakhri (2005) who studied the organic matter in a station near the Selaata sediments. It was attributed to changes in the nature of the waste discharged by the phosphorgypsum plant probably linked to different phosphate ore sources. This hypothesis, which is also the reason for the $\mathrm{Hg}$ vertical profile obtained in S3, cannot be verified historically because of difficulties in obtaining information on any modifications in the process applied in the Selaata chemical power plant. However, based on our mineralogical analysis, the Selaata sediment core, even at the deepest layers, is rich in fluorite (25-55\%) which is a compound naturally present in the phosphate rock $\mathrm{Ca}_{3}(\mathrm{PO} 4)_{2}$ processed in the Selaata plant (AlHajj and Muscat 2000) (see Fig. 3c). This finding testifies to the dominance of industrial deposits in 
the sediments studied. In addition, the vertical profile of excess ${ }^{210} \mathrm{~Pb}$ indicates that the sediments are recent. Thus, the vertical mercury profile, or any other major and trace element profile will be largely influenced by the composition of the $\mathrm{Ca}_{3}(\mathrm{PO} 4)_{2}$ used as raw material in the Selaata chemical plant. At the S6 sediment core, the 2 layer profile was not observed. The HgT concentrations exhibit several smaller fluctuations within the first $8 \mathrm{~cm}$, and then they increase slowly toward the deepest $(8-16 \mathrm{~cm}$ ) layers (Fig. 3c). This mercury profile, which persists after normalizing mercury to Al, can be explained by the position of S6 in a bay North of the Selaata plant, and thus relatively more protected than S3 from the direct discharges of phosphogypsum and associated impurities. This position of S6 allows total mercury in the sediments to attain a more constant profile.

In summary, the $\mathrm{HgT}$ concentrations found in the sediment cores of the three bays on the Lebanese coast studied, which ranged from 0.01 to $0.65 \mu_{\mathrm{g} \mathrm{g}}^{-1}$, testified to various degrees of anthropogenic contamination. At Akkar the sediment recently deposited gave evidence of a limited diffuse anthropogenic contribution, at Dora Bay the sediments are heavily polluted and at Selaata the $\mathrm{Hg}$ contamination is directly related to the industrial waste flowing out into the Bay. For comparison with our results, the few mercury studies of Eastern Mediterranean coastal sediments showed some degree of mercury contamination $\left(0.05-0.70 \mu \mathrm{g} \mathrm{g}^{-1}\right)$ in the inner part of Haifa Bay while concentrations in the outer coastal sediments range between values lower than 0.001 and up to $0.054 \mu^{-1}$ g (Krumgalz and Fainshtein 1991; Herut et al. 1993). North of this area, along the Lebanese coast, Nassif (2004) measured mercury concentration in surface sediments ranging from 0.01 to $0.46 \mu \mathrm{g} \mathrm{g}^{-1}$ with the highest concentrations obtained at Antélias, the highly urbanized and industrialized zone located near Beirut, and in the Selaata Port sediments (see Table 2).

\subsection{Methylmercury}

\subsubsection{Distributions}

Particulate methylmercury (MeHg) concentrations were measured in the solid phase of Akkar ( $\left.A^{\prime}\right)$, Dora (D') and Selaata (S1) sediments. Concentrations obtained for Akkar and Dora sediments are presented in figure 5, MeHg concentrations in Selaata sediments were below the detection limits $\left(0.02 \mathrm{ng} \mathrm{g}^{-1}\right)$. These aforementioned low particulate $\mathrm{MeHg}$ concentrations in Selaata sediments can be due to the fact that the studied deposits result mostly from the wastes discharged by the nearby phosphogypsum industry (see paragraph 3.1.1). MeHg concentrations in the solid phase of the Akkar A' sediment core varied from 0.03 to $0.22 \mathrm{ng} \mathrm{g}^{-1}$, with high $\mathrm{MeHg}$ concentrations obtained at the $2.5-10.5 \mathrm{~cm}$ sediment layers. However, higher $\mathrm{MeHg}$ concentrations were obtained in Dora sediment $\left(0.07-0.5 \mathrm{ng} \mathrm{g}^{-1}\right.$ ) where the $\mathrm{MeHg}$ depth profile is characterized by a downcore decrease (Fig. 5).

MeHg concentrations are very low in comparison with some coastal polluted sediment in the Mediterranean Sea such as the Gulf of Trieste where particulate MeHg concentrations vary from 0.2 to $60.1 \mathrm{ng} \mathrm{g}^{-1}$ (Covelli et al. 2001). However, they are in the range of concentrations in the coastal Mediterranean sediments of the same region $\left(0.09-0.61 \mathrm{ng} \mathrm{g}^{-1}\right.$; Shoham-Frider et al. 2007), or in Western Mediterranean sediments of the Thau lagoon (0.08-2.75 $\mathrm{ng} \mathrm{g}^{-1}$; Muresan et al. 2007) or again in other unimpacted coastal areas in the world: $0.05-1.5 \mathrm{ng} \mathrm{g}^{-1}$ (Bay of Fundy, Sunderland et al. 2006). Significant $(\mathrm{p}<0.01)$ positive correlation was found between $\mathrm{MeHg}$ and $\mathrm{HgT}$ in the solid phase of Akkar sediment $\left([\mathrm{MeHg}]\left(\mathrm{ng} \mathrm{g}^{-1}\right)=0.005\left[\mathrm{HgT}^{-}\left(\mathrm{ng} \mathrm{g}^{-1}\right)-0.008 ; \mathrm{R}^{2}=0.5 ; n=\right.\right.$ 24). This later significant positive correlation are often detected at low levels of HgT (MarvinDipasquale et al. 2009) which is not the case of Dora sediment where no significant positive correlation was found between particulate $\mathrm{MeHg}$ and $\mathrm{HgT}$. This suggests that in polluted environment, such as Dora, inorganic $\mathrm{Hg}$ is not a limiting factor for $\mathrm{Hg}$ methylation. 
$\mathrm{MeHg}$ concentrations in the solid phase of Akkar and Dora sediments correspond to $0.2-1 \%$ of total mercury in the Akkar sediments and to $0.03-0.35 \%$ of total mercury in the Dora sediments. These percentages, which can be used as a proxy for the rate of mercury methylation (Hammerschmidt and Fitzgerald 2004; Hammerschmidt and Fitzgerald 2006; Drott et al. 2008), suggest that $\mathrm{MeHg}$ production in the Dora sediments could be relatively low, though higher variable methylation rates were obtained in the Akkar sediment core, especially in the upper $18 \mathrm{~cm}$ levels of the sediment core. The relatively low contribution of $\mathrm{MeHg}$ to $\mathrm{Hg}_{\mathrm{T}}$ in the solid phase of the Dora sediments could be due to Dora's higher total mercury concentrations and might also indicate a limited methylation rate in the presence of high sulphide concentrations (Benoit et al. 1999; Castelle et al. 2007).

$\mathrm{MeHg}_{\mathrm{D}}$ concentrations were determined in the interstitial waters of the Dora and Selaata sediments and in the overlying waters, in order to explore the possible evasion of this mercury species from these contaminated sediments. In the interstitial waters, the $\mathrm{MeHg}_{\mathrm{D}}$ concentrations ranged from 0.04 to 0.09 and from 0.04 to $8.76 \mathrm{ng} \mathrm{L}^{-1}$ in the Selaata and the Dora sediments respectively; in the overlying water they were below the limit of detection $\left(0.020 \mathrm{ng} \mathrm{L}^{-1}\right)$. The levels are similar to those expected in coastal sediments (Muresan et al. 2007). In the interstitial waters the variation of $\mathrm{MeHg}_{\mathrm{D}}$ exhibited sub-intersurface maxima peaking at $8.76 \mathrm{ng} \mathrm{L}^{-1}$ in core $\mathrm{D}$ at the Dora site (Fig. 6), which suggest mercury in situ methylation at those depths due to the activity of sulphate reducing bacteria in the suboxic zone of the sediment (e.g., Compeau and Bartha 1985; Langer et al. 2001; Muresan et al. 2007).

\subsubsection{Fluxes}

The possible diffusion flux of $\mathrm{MeHg}_{\mathrm{D}}$ from the Dora and Selaata sediments to the overlying water column is estimated by applying Fick's first law. The concentration gradient between $\mathrm{MeHg}_{\mathrm{D}}$ concentrations in the upper $2 \mathrm{~cm}$ sediment layer of Dora (D) and Selaata (S6), and the overlying water is used to estimate $\mathrm{MeHg}_{\mathrm{D}}$ diffusive flux at the sediment-water interface. In fact, if we consider that the transfer of $\mathrm{MeHg}_{\mathrm{D}}$ from sediments to the water column is proportional to the concentration gradient, we can apply Fick's First Law (eq.1) described by Berner (1980) to calculate $\mathrm{MeHg}_{\mathrm{D}}$ flux (Choe et al. 2004; Hammerschmidt and Fitzgerald 2006; Muresan et al. 2007; Ogrinc et al. 2007).

$$
\text { Flux }=-\varnothing D_{s}\left(C_{w}-C\right) / h
$$

Where $\varnothing$ is the porosity of the sediment (volume of pore water/ volume of bulk sediment), $C$ is the concentration of $\mathrm{MeHg}_{\mathrm{D}}$ in pore water sediment, $\mathrm{C}_{\mathrm{W}}$ is the concentration of the overlying water (ng $\left.\mathrm{L}^{-1}\right), \mathrm{h}$ is the depth of the sediment $(\mathrm{cm})$ and $D_{S}$ is the whole sediment molecular diffusion coefficient $\left(\mathrm{cm}^{2} \mathrm{~s}^{-1}\right)$.

The benthic flux estimation will allow us to obtain a first order approximation of the transport of $\mathrm{MeHg}$ from Dora and Selaata sediments to the overlying water column, especially since studies conducted by Choe et al. (2004) have shown that sediments with high estimated diffusive flux also have high directly measured diffusive flux and vice versa. Since there is no data available concerning the $D_{S}$ in our sediments, we used values calculated for comparable Mediterranean sediments at the Thau Lagoon (France) (Muresan et al. 2007) with the assumption that $\mathrm{MMHg}_{\mathrm{D}}$ was as methylmercury chloride $\left(D_{S}=1.84 \times 10^{-5} \mathrm{~cm}^{2} \mathrm{~s}^{-1}\right)$. Similarly, the sediment porosity was estimated to be 0.853 . The concentration of $\mathrm{MeHg}_{\mathrm{D}}$ obtained at the $2 \mathrm{~cm}$ sediment layers is used for the pore water value and is applied to $2 \mathrm{~cm}$ depth for the flux calculation. The concentrations of $\mathrm{MeHg}$ in the overlying water $\mathrm{C}_{\mathrm{w}}$ is fixed at $0.02 \mathrm{ng} \mathrm{L}^{-1}$ since measured values were below the detection limit of $<0.04 \mathrm{ng} \mathrm{L}^{-1}$. 
Results of calculated diffusive fluxes for Dora and Selaata sediments are presented in table 3. Although Dora diffusive flux is almost three times higher than Selaata diffusive flux, Dora and Selaata diffusive fluxes (Table 3) are comparable to $\mathrm{MeHg}$ diffusive flux in other coastal Mediterranean sediments, such as the Thau Lagoon $\left(0.8 \pm 0.4 \mathrm{ng} \mathrm{m}^{2}\right.$ day $^{-1}$; Muresan et al. 2007) and are also comparable to the lowest values obtained at deep Mediterranean sediment layers (0.6-6.4 $\mathrm{ng} \mathrm{m}^{2}$ day $^{-1}$; Ogrinc et al. 2007) and at the Lavaca Bay (0.4-1400 $\mathrm{ng} \mathrm{m}^{2}$ day $^{-1}$; Gill et al. 1999), and are $10-10^{2}$ less than those measured or calculated in other near-shore polluted sediments such as the Gulf of Trieste in the northern Adriatic sea, where MeHg diffusive flux reaches values of $40 \mathrm{ng} \mathrm{m}^{2}$ day $^{-1}$ (Covelli et al. 1999). In spite of the low estimated molecular diffusive flux of $\mathrm{MeHg}$ measured here, the deposited sediments constitute a measurable source of bioavailable mercury for epibenthic organisms. Indeed, according to Benoit et al. (2009) the estimated diffusive flux constitutes only a small fraction $(<10 \%)$ of the real diffusive flux and also benthic organisms can assimilate $\mathrm{MeHg}$ directly from deep anoxic sediment layers, and thus transfer it to fish through the aquatic food web and to human consumers.

\section{Summary and conclusions}

The sediment cores from the three bays along the studied Lebanese coast (Akkar, Dora and Selaata) are mostly composed of carbonate materials and quartz, with the specific presence of fluorite at the Selaata Point. Chemical composition, dating and mineralogy demonstrate that the sediment in the Akkar bay, located away from any direct source of contamination, comes mostly from the erosion of local rocks, while in the Dora bay, located near an enormous dumping site is subject to industrial and urban contamination, and at the Selaata Point, located near a chemical plant, they are typically characteristic of phosphogypsum industrial wastes. Analyses of total mercury ( $\mathrm{HgT}$ ) in the solid phase of the sediment allow us to point out an important $\mathrm{Hg}$ contamination at Dora, near the huge dumpsite, which functioned from 1980 to 1998. The highest measured level $\left(0.65 \mu \mathrm{g} \mathrm{g}^{-1}\right)$ encompasses the sediment quality guidelines developed for the National Status and Trends Program in USA by the National Oceanographic and Atmospheric Administration (NOAA, 1999) based on works by MacDonald et al. (2000). Concentrations most often exceed the "consensus based threshold effect" level $\left(0.17 \mu \mathrm{g} \mathrm{g}^{-1}\right)$ and the highest almost reach the "effects range-medium" level $\left(0.71 \mu \mathrm{g} \mathrm{g}^{-1}\right)$. In spite of the low $\mathrm{HgT}$ concentrations in Akkar and Selaata sediment (similar to natural carbonated sediment: $0.04 \mathrm{\mu g} \mathrm{g}^{-1}$ according to Turekian and Wedephol, 1961), a closer analysis of sediment cores vertical profiles allow to observe an anthropogenic impact. This impact may be toxicologically insignificant, but allows to trace time increase of $\mathrm{Hg}$ diffuse deposition. At Selaata the $\mathrm{Hg}$ contamination is directly related to the phosphogypsum waste flowing out into the Bay. However, the HgT encountered were low compared to what should be expected from the exploitation of phosphate rocks in other parts of the world. At Akkar, even if the $\mathrm{HgT}$ in the sediments ranged within the earth crust values, a close examination of the results, by using a comparison of the $\mathrm{Hg}$ profile with the $\mathrm{Pb}$ stable isotopic profiles obtained for the same core (Abi-Ghanem et al. 2009), allows to suggest an anthropogenic contribution.

The methylmercury measurements in those sediments indicate relatively low levels $(0.03-0.5 \mathrm{ng}$ $\mathrm{g}^{-1}$ ) and show that this species represents less than $1 \%$ of the $\mathrm{HgT}$ present in the solid phase. Dissolved $\mathrm{MeHg}$ concentrations, estimated as a risk assessment" complementary method (Skyllberg et al. 2007), were measured in the pore waters of the Dora and the Selaata sediments ( 0.04 to $\left.8.76 \mathrm{ng} \mathrm{L}^{-1}\right)$; the concentrations present vertical profiles allowing the calculation of low diffusive fluxes out of the sediment toward the water column, $\left(0.7\right.$ and $\left.0.3 \mathrm{ng} \mathrm{m}^{-2} \mathrm{~d}^{-1}\right)$ at the Dora and Selaata sediments, respectively. These fluxes constitute sources for the exposition of coastal 
ecosystems to this toxic chemical, which is further added to the MeHg incorporated via the benthic food webs.

\section{Acknowledgements}

We gratefully acknowledge the skilful help of E. Teirik, D. Auger, B. Averty and E. Rozuel in the sampling operation and for their analytical assistance. This research was funded by the CEDRE

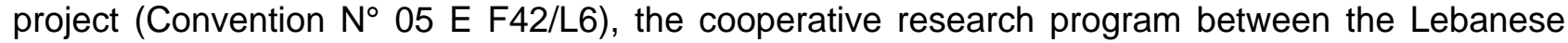
CNRS and Ifremer (Convention Cadre $N^{\circ}$ 07/1216532), and the AUF, which provides funding for student residence time in France.

\section{References}

Abdel-Rahman A, Nader F (2002) Characterization of the Lebanese Jurassic-Cretaceous carbonate stratigraphic sequence: a geochemical approach. Geol J 37: 69-91.

Abi-Ghanem C, Chiffoleau JF, Bermond A, Nakhlé K, Borschneck D, Khalaf G, Cossa D (2009) Lead and its isotopes in the sediment of three sites of the Lebanese coasts: Estimation of contamination sources. Appl Geochem 24: 1990-1999.

Ackermann F, Bergmann M, Schleichert GU (1983) Monitoring of heavy metals in coastal and estuarine sediments-a question of grain size: $<20 \mu \mathrm{m}$ versus $<60 \mu \mathrm{m}$. Environ Technol Lett 4: 317-328.

Al-Hajj Z, Muscat C (2000) From Europe to the Mediterranean. A Greenpeace report focusing on pollution by the fertilizer industry and the shift of such dirty technologies from Europe to developing countries in the Mediterranean.

Baldi F, Bargagli R, Focardi S, Fossi C (1983) Mercury and chlorinated hydrocarbons in sediments from the bay of Naples and adjacent marine areas. Mar Poll Bull 14: 108-111.

Benoit JM, Gilmour CC, Mason RP, Heyes A (1999) Sulfide controls on mercury speciation and bioavailability to methylating bacteria in sediment pore waters. Environ Sci Technol 33: 951957.

Benoit JM, Shull DH, Harvey RM, Beal SA (2009) Effect of bioirrigation on sediment-water exchange of methylmercury in Boston Harbor, Massachusetts. Environ Sci Thechnol, In press.

Berner RA (1980) Early Diagenesis: A Theoretical Approach. Princeton Univ Press, Princeton, NJ. (cited by Ogrinc et al. 2007).

Bernhard M, Renzoni A (1977) Mercury concentration in Mediterranean marine organisms and their environment: natural and anthropogenic origin. Thalass Jugosl 13: 265-300.

Castelle S, Schafer J, Blanc G, Audry S, Etcheber H, Lissalde J-P (2007) 50-year record and solid state speciation of mercury in natural and contaminated reservoir sediment. Appl Geochem 22: 1359-1370.

CDR/ ECODIT-IAURIF (1997) Council for Development and Reconstruction. Regional Environmental Assessment Report on the Coastal Zone of Lebanon. Final Report. Prepared by ECODIT/ IAURIF.

Choe K-Y, Gill GA, Lehman RD, Han S, Heim WA, Coale KH (2004) Sediment-water exchange of total mercury and monomethyl mercury in the San Francisco Bay-Delta. Limnol Ocean 49: 1512-1527.

Compeau GC, Bartha R (1985) Sulfate-reducing bacteria: principal methylators of mercury in anoxic estuarine sediment. Appl Environ Microbiol 50: 498-502.

Cossa D, Averty B, Bretaudeau J, Sénard AS (2003) Spéciation du mercure dissous dans les eaux marines. Dosage du mercure total, gazeux, réactif, mono et diméthylmercure. Méthodes 
d'analyse en milieu marin. Co-édition Ifremer et ministère de l'Ecologie et du développement durable.

Cossa D, Coquery M (2005) The Mediterranean mercury anomaly, a geochemical or a biological issue. In: Saliot A (ed) The Mediterranean Sea. Handbook of Environmental Chemistry, vol. V. Springer, pp. 177-208.

Cossa D, B Averty Pirrone N (2009) The origin of methylmercury in open Mediterranean waters. Limnol Ocean 54: 837-844.

Covelli S, Faganelli J, Horvat M, Brambati A (1999) Porewater distribution and benthic flux measurements of mercury and methylmercury in the Gulf of Trieste (North Adriatic Sea). Estuar Coast SchelfSci 48: 415-428.

Covelli S, Faganelli J, Horvat M, Brambati A (2001) Mercury contamination of coastal sediments of long-term cinnabar mining activity (Gulf of Trieste, northern Adriatic Sea). Appl Geochem 16: 541-558.

Di Leonardo R, Tranchida G, Bellanca A, Neri R, Angelone M, Mazzola S (2006) Mercury levels in sediments of central Mediterranean Sea: A 150+ year record from box-cores recovered in the Strait of Sicily. Chemosphere 65: 2366-2376.

Drott A, Lambertsson L, Bjorn E, Skyllberg U (2008) Do Potential Methylation Rates Reflect Accumulated Methyl Mercury in Contaminated Sediments? Environ Sci Technol 42: 153-158.

Fakhri M (2005) Interactions de deux sources continentales, naturelle et anthropogénique, sur les caractéristiques physico-chimiques et biologiques du milieu marin de Batroun au Liban Nord (Méditerranée Orientale). Ph.D. Thesis, University of the Mediterranean (Aix Marseille II), France.

Fitzgerald WF, Lamborg CH (2003) Geochemistry of mercury in the environment. In: Lollar BS (ed.), Treatise on Geochemistry, vol. IX. Elsevier, Amsterdam, pp. 107-148.

Fitzgerald WF, Lamborg CH, Hammerschmidt CR (2007) Marine Biogeochemical Cycling of Mercury. Chem Rev 107:641-662.

French Geode Program (2000) French law on water $n^{\circ} 92.3$ ( $3^{\text {rd }}$ January 1992), Decree of June the $\left.14^{\text {th }} 2000\right)$. Journal Officiel, République Française (http://www.ifremer.fr/delcc/cycleau/reglementation/dragages.htm).

Gill GA, Bloom NS, Cappellino S, Driscoll CT, Mason R, Rudd JWM (1999) Sediment-water fluxes of mercury in Lavaca Bay, Texas. Environ Sci Technol 33: 663-669.

Hammerschmidt CR, Fitzgerald WF (2004) Geochemical controls on the production and distribution of methylmercury in near-shore marine sediments. Environ Sci Technol 38: 14871495.

Hammerschmidt CR, Fitzgerald WF (2006) Methylmercury cycling in sediments on the continental shelf of southern New England. Geochim Cosmochim Acta 70: 918-930.

Herut B, Hornung H, Krom MD, Kress N, Cohen Y (1993) Trace Metals in Shallow Sediments from the Mediterranean Coastal Region of Israel. Mar Poll Bull 26: 675-682.

Hesslein RH (1976) An in-situ sampler for close interval pore water studies. Limnol Oceanogr 21:912-914.

Jackson M, Hancock D, Schulz R, Talbot V, William D (1986) Rock phosphate: The source of mercury pollution in a marine ecosystem at Albany, Western Australia. Mar Environ Res 18: 185-202.

Kersten M, Smedes F (2002) Normalization procedures for sediment contaminants in spatial and temporal trend monitoring. J Environ Monit 4: 109-115.

Krumgalz BS, Fainshtein G (1991) Trace metals and organic matter in nearshore sediment cores from the Eastern Mediterranean (Haifa Bay of Israel). Mar Environ Res 31: 1-15.

Langer CS, Fitzgerald WF, Visscher PT, Vandal GM (2001) Biogeochemical cycling of methylmercury at Barn Island Salt Marsh, Stonington, CT, USA. Wet Ecol Manag 9: 295-310. 
Loring DH, Rantala RTT (1990) Sediments and suspended particulate matter: total and partial methods of digestion. ICES Tech Mar Environ Sci 9:14 p.

MacDonald, D.D., C.G. Ingersoll, T.A. Berger (2000) Development and evaluation of consensusbased sediment quality guidelines for freshwater ecosystems. Arch Environ Contam Toxicol 39: 20-31.

Marvin-Dipasquale M, Lutz AM, Brigham EM, Krabbenhoft PD, Aiken RG, Orem HW, Hall DB (2009) Mercury Cycling in Stream Ecosystems. 2. Benthic Methylmercury Production and Bed Sediment-Pore Water Partitioning. Environ Sci Technol 43: 2726-2732.

METAP/Tebodin (1998) Ministry of Environment. Industrial Pollution Control Lebanon. Prepared by Tebodin and financed by the World Bank and UNIDO.

Monperrus M, Tessier E, Veschambre S, Amouroux D, Donnard O (2005) Simoultaneous speciation of mercury and butyltin compounds in natural waters and snow by propylation and species-specific isotope dilution mass spectrometry analysis. Anal Bioanal Chem 381: 854862.

Morel MMF, Kraepiel MLA, Amyot M (1998) The chemical cycle and bioaccumulation of mercury. Annu Rev Ecol Sys 29: 543-566.

Morse JW (2003) Formation and diagenesis of Carbonate sediments. In: Lollar SB, Holland HD, Turequian KK (eds.), Treatise on Geochemistry, vol. VII. Elsevier, pp. 67-85.

Mouawad R (2005) Peuplements de Nématodes de la zone littorale des côtes du Liban. Ph.D. Thesis, University of the Mediterranean (Aix Marseille II), France.

Muresan B, Cossa D, Jézéquel D, Prévot F, Kerbellec S (2007) The biogeochemistry of mercury at the sediment-water interface in the Thau lagoon. 1. Partition and speciation. Estuar Coast Shelf Sci 72: 472-484.

Nakhlé K (2003) Le mercure, le Cadmium et le Plomb dans les eaux littorales libanaises: Apports et suivi au moyen de bioindicateurs quantitatifs (Eponges, bivalves et gasteropodes). Ph.D. Thesis, University of Paris 7 Denis Diderot, France.

Nassif N (2004) Pollutions chimiques en milieu marin: essai de modélisation et approche réglementaire. Ph.D. Thesis, AgroParisTech, France.

NOAA (1999) National Oceanographic and Atmospheric Administration. ccma.nos.noaa.gov/publications/sqg.pdf.

Ogrinc N, Monperrus M, Kotnik J, Fajon V, Vidimova K, Amouroux D, Kocman D, Tessier E, Zizek S, Horvat M (2007) Distribution of mercury and methylmercury in deep-sea surficial sediments of the Mediterranean Sea. Mar Chem 107: 31-48.

Pirrone N, Costa P, Pacyna JM, Ferrara R (2001) Mercury emissions to the atmosphere from natural and anthropogenic sources in the Mediterranean region. Atmos Environ 35: 29973006.

Pirrone N, Ferrara R, Hedgecock IM, Kallos G, Mamane Y, Munthe J, Pacyna JM, Pytharoulis I, Sprovieri F, Voudouri A, Wangberg I (2003) Dynamic processes of mercury over the Mediterranean region: results from the Mediterranean Atmospheric Mercury Cycle System (MAMCS) project. Atmos Environ 37 Supplement No. 1: S21-S39.

Sanchez Uria JE, Sanz-Mendel A (1998) Inorganic and methylmercury speciation in environmental samples. Talanta 47:509-524.

Sanchiz C, Garcia-Carrascosa AM, Pastor A (2000) Heavy metal content in soft-bottom marine macrophytes and sediments along the Mediterranean coast of Spain. Mar Ecol 21:1-16.

Sanlaville P (1977) Etude géomorphologique de la région du littorale du Liban. The Lebanese University (ed.), vol I.

Shoham-Frider E, Shelef G, Kress N (2007) Mercury speciation in sediments at a municipal sewage sludge marine disposal site. Mar Environ Res 64: 601-615.

Sunderland EM, Gobas APCF, Branfireun AB, Heyes A (2006) Environmental controls on the speciation and distribution of mercury in coastal sediments. Mar Chem 102: 111-123.

Syllberg U, Drott A, Lambertsson L, Björn E, Karlsson T, Johnson T, Heinemo S- $\AA$, Holmström H Net Methylmercury Production as a Basis for Improved Risk Assessment of Mercurycontaminated Sediments. Ambio 36: 437-442. 
Tomiyasu T, Matsuyama A, Eguchi T, Fuchigami Y, Okiki K, Horvat M, Rudi R, Akagi H (2006) Spatial Variations of mercury in sediment of Minamata Bay, Japan. Sci Tot Environ 368: 283290.

Tseng CM, de Diego A, Pinaly H, Amouroux D, Donard OFX (1998) Cryofocusing coupled to atomic adsorption spectrometry for rapid and simple mercury speciation in environmental matrices. J Anal Atom Spectrom 13: 755-764.

Turekian KK, Wedephol KH (1961) Distribution of the elements in some major units of the earth's crust. Geol Soc Am Bull 72:175-192. (Cited by Fitzgerald and Lamborg 2003).

\section{Tables}

Table 1. Description of the core sampling sites (see also figure 1).

\begin{tabular}{|c|c|c|c|}
\hline Site & Core name & Coordinates (latitude, longitude) & Water column depth $(\mathrm{m})$ \\
\hline Akkar & $A$ & $34^{\circ} 33^{\prime} 700 \mathrm{~N} ; 035^{\circ} 58^{\prime} 127 \mathrm{E}$ & 18.5 \\
\hline Akkar & $A^{\prime}$ & $34^{\circ} 33^{\prime} 669 \mathrm{~N} ; 035^{\circ} 58^{\prime} 705 \mathrm{E}$ & 14.5 \\
\hline Selaata & $\mathrm{S} 1$ & $34^{\circ} 16^{\prime} 770 \mathrm{~N} ; 035^{\circ} 39^{\prime} \mathrm{OOOE}$ & 7.5 \\
\hline Selaata & S3 & $34^{\circ} 16^{\prime} 779 \mathrm{~N} ; 035^{\circ} 39^{\prime} 008 \mathrm{E}$ & 14 \\
\hline Selaata & S4 & $34^{\circ} 16^{\prime} 779 \mathrm{~N} ; 035^{\circ} 39^{\prime} 008 \mathrm{~N}$ & 6 \\
\hline Selaata & S6 & $34^{\circ} 17^{\prime} 20 \mathrm{~N} 5 ; 035^{\circ} 39^{\prime} 685 \mathrm{E}$ & 15 \\
\hline Dora & $\mathrm{D}$ & $33^{\circ} 54^{\prime} 155 \mathrm{~N} ; 035^{\circ} 33^{\prime} 218 \mathrm{E}$ & 8 \\
\hline Dora & $D^{\prime}$ & $33^{\circ} 54^{\prime} 213 \mathrm{~N} ; 035^{\circ} 33^{\prime} 240 \mathrm{E}$ & 7.5 \\
\hline
\end{tabular}


Table 2. Concentrations of total mercury $(\mathrm{HgT})$ in Lebanese marine sediments relative to other regions.

\begin{tabular}{|c|c|c|c|c|}
\hline Region & $\mathrm{HgT}\left(\mu \mathrm{g} \mathrm{g}{ }^{-1}\right)$ & $\begin{array}{l}\text { Digestion } \\
\text { method }\end{array}$ & $\begin{array}{l}\text { Nature of } \\
\text { sediment }\end{array}$ & Reference \\
\hline $\begin{array}{l}\text { Deep sea surficial } \\
\text { sediments of the Levantine } \\
\text { basin }\end{array}$ & 0.04 & $\begin{array}{l}\mathrm{HNO}_{3} / \mathrm{HF}(2: 1) \\
\text { and conc. } \mathrm{HCl}\end{array}$ & $\begin{array}{l}\text { Carbonate }+ \\
\text { aluminosilicate }\end{array}$ & $\begin{array}{l}\text { Ogrinc et al. } \\
\quad(2007)\end{array}$ \\
\hline $\begin{array}{l}\text { Coastal marine sediments of } \\
\text { Western Mediterranean }\end{array}$ & $0.01-0.32$ & $\mathrm{HNO}_{3}$ & - & $\begin{array}{l}\text { Sanchiz et al. } \\
\quad(2000)\end{array}$ \\
\hline $\begin{array}{l}\text { Background } \begin{array}{l}\text { coastal } \\
\text { sediments of Eastern } \\
\text { Mediterranean }\end{array} \\
\end{array}$ & $\begin{array}{l}0.0157- \\
0.073\end{array}$ & Aqua-Regia & - & $\begin{array}{l}\text { Shoham-Frider } \\
\text { et al. (2007) }\end{array}$ \\
\hline $\begin{array}{l}\text { Polluted sediment of Haifa } \\
\text { Bay }\end{array}$ & $0.1-0.4$ & $\mathrm{HNO}_{3}$ & $\begin{array}{l}\text { Carbonate } \\
\text { sediments }\end{array}$ & $\begin{array}{l}\text { Krumgalz and } \\
\text { Fainshtein } \\
\text { (1991) }\end{array}$ \\
\hline $\begin{array}{l}\text { Polluted sediments of } \\
\text { Minamata Bay (Pacific) }\end{array}$ & $0.34-4.83$ & $\begin{array}{c}\mathrm{HNO}_{3} / \mathrm{HCl}(1: 1) \\
\text { and conc. } \\
\mathrm{H}_{2} \mathrm{SO}_{4}\end{array}$ & - & $\begin{array}{l}\text { Tomiyasu et al. } \\
\quad(2006)\end{array}$ \\
\hline $\begin{array}{l}\text { Polluted coastal sediments } \\
\text { of the Gulf of Trieste } \\
\text { (Adriatic sea) }\end{array}$ & $0.1-23.3$ & $\mathrm{HNO}_{3}$ & $\begin{array}{l}\text { Carbonate } \\
\text { sediments }\end{array}$ & $\begin{array}{l}\text { Covelli et al. } \\
\quad(2001)\end{array}$ \\
\hline $\begin{array}{l}\text { Lebanese coastal marine } \\
\text { sediments: Selaata }\end{array}$ & 0.02 & Aqua-Regia & Sandy sediments & Nassif (2004) \\
\hline $\begin{array}{l}\text { Lebanese coastal marine } \\
\text { sediments: Batroun }\end{array}$ & 0.01 & Aqua-Regia & Sandy sediments & Nassif (2004) \\
\hline $\begin{array}{l}\text { Lebanese coastal marine } \\
\text { sediments: Antélias }\end{array}$ & $0.02-0.46$ & Aqua-Regia & Sandy sediments & Nassif (2004) \\
\hline $\begin{array}{l}\text { Lebanese coastal marine } \\
\text { sediments: Akkar }\end{array}$ & $0.01-0.04$ & $\begin{array}{c}550^{\circ} \mathrm{C} \\
\text { decomposition }\end{array}$ & $\begin{array}{l}\text { Carbonate } \\
\text { sediments }\end{array}$ & This study \\
\hline $\begin{array}{l}\text { Lebanese coastal marine } \\
\text { sediments: Dora }\end{array}$ & $0.1-0.65$ & $\begin{array}{c}550^{\circ} \mathrm{C} \\
\text { decomposition }\end{array}$ & $\begin{array}{l}\text { Quartz + } \\
\text { carbonates }\end{array}$ & This study \\
\hline $\begin{array}{l}\text { Lebanese coastal marine } \\
\text { sediments: Selaata }\end{array}$ & $0.02-0.06$ & $\begin{array}{c}550^{\circ} \mathrm{C} \\
\text { decomposition }\end{array}$ & $\begin{array}{l}\text { Quartz + fluorite + } \\
\text { carbonates }\end{array}$ & This study \\
\hline
\end{tabular}


Table 3. Dissolved MeHg diffusive fluxes from the sediments to the water column. Dora and Selaata bays surface areas are 800 and $10^{7} \mathrm{~m}^{2}$ respectively.

Dora (core D) Selaata (core S6)

\begin{tabular}{lcc}
\hline Flux $\left(\mathrm{pmol} \mathrm{m}^{2}\right.$ day $\left.^{-1}\right)$ & 3.73 & 1.76 \\
Flux $_{\text {integrated }}\left(\mathrm{pmol} \mathrm{day}^{-1}\right)$ & $2.98 \times 10^{3}$ & $1.76 \times 10^{7}$
\end{tabular}


Eastern

\section{Eastern}

Mediterranean Sea

Mediterranean Sea

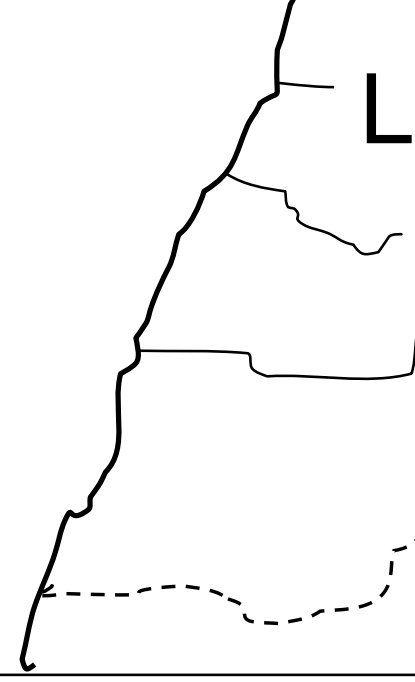

\section{Selaata \\ Cores S1 to S6}

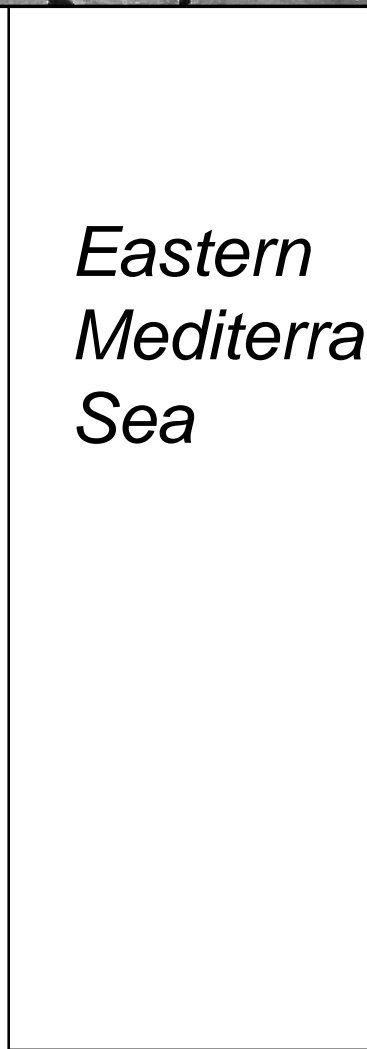


Figure 2. Ternary plot of major elements of Akkar, Dora and Selaata (S3 and S6) sediments

$\mathrm{SiO}_{2}(\%)$

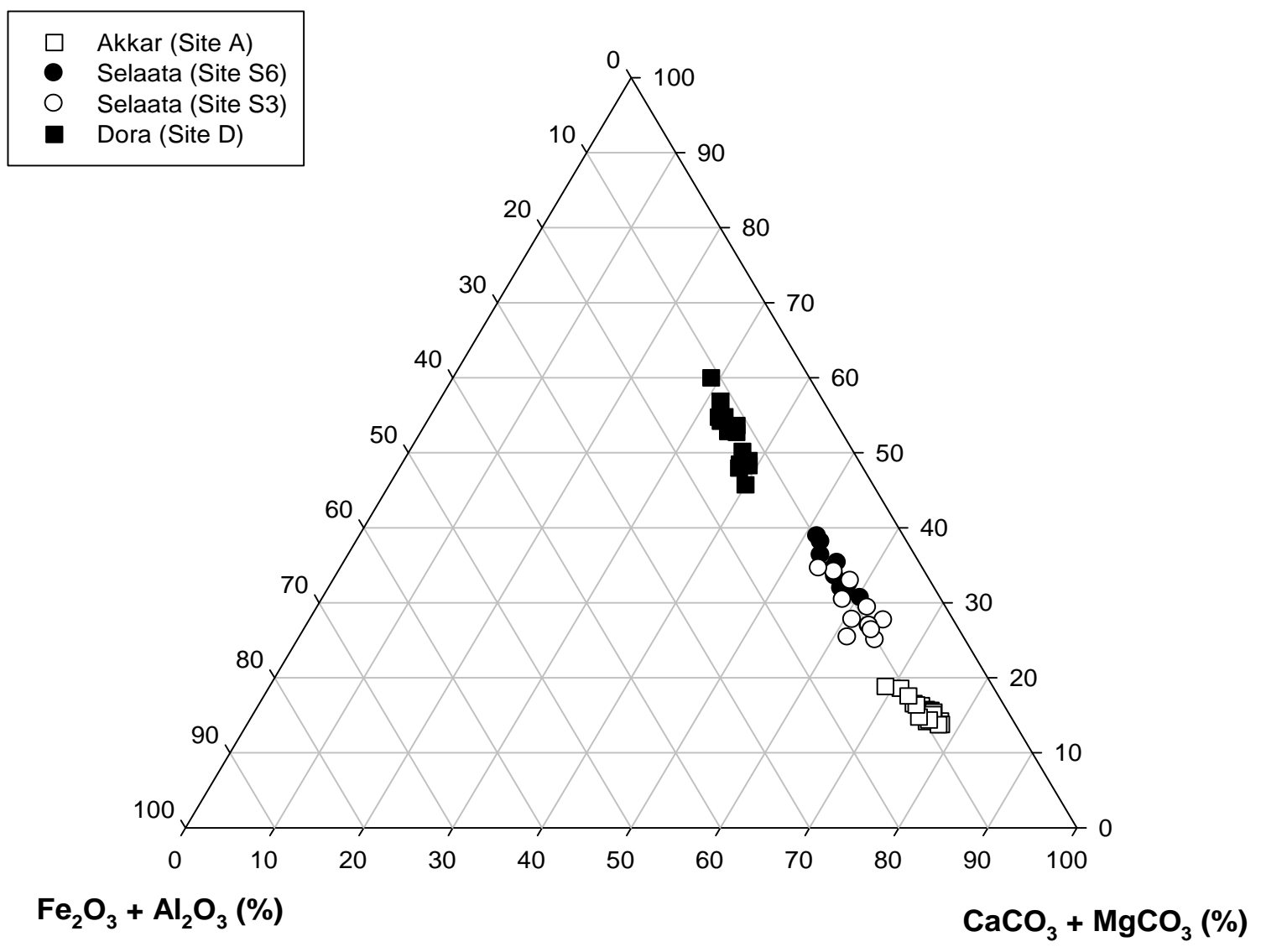


Figure 3. Vertical profiles of mercury and mercury normalized to Al in (a) Akkar (A, A') sediments, (b) Dora (D, D') sediments and in (c) Selaata (S3, S6) sediments

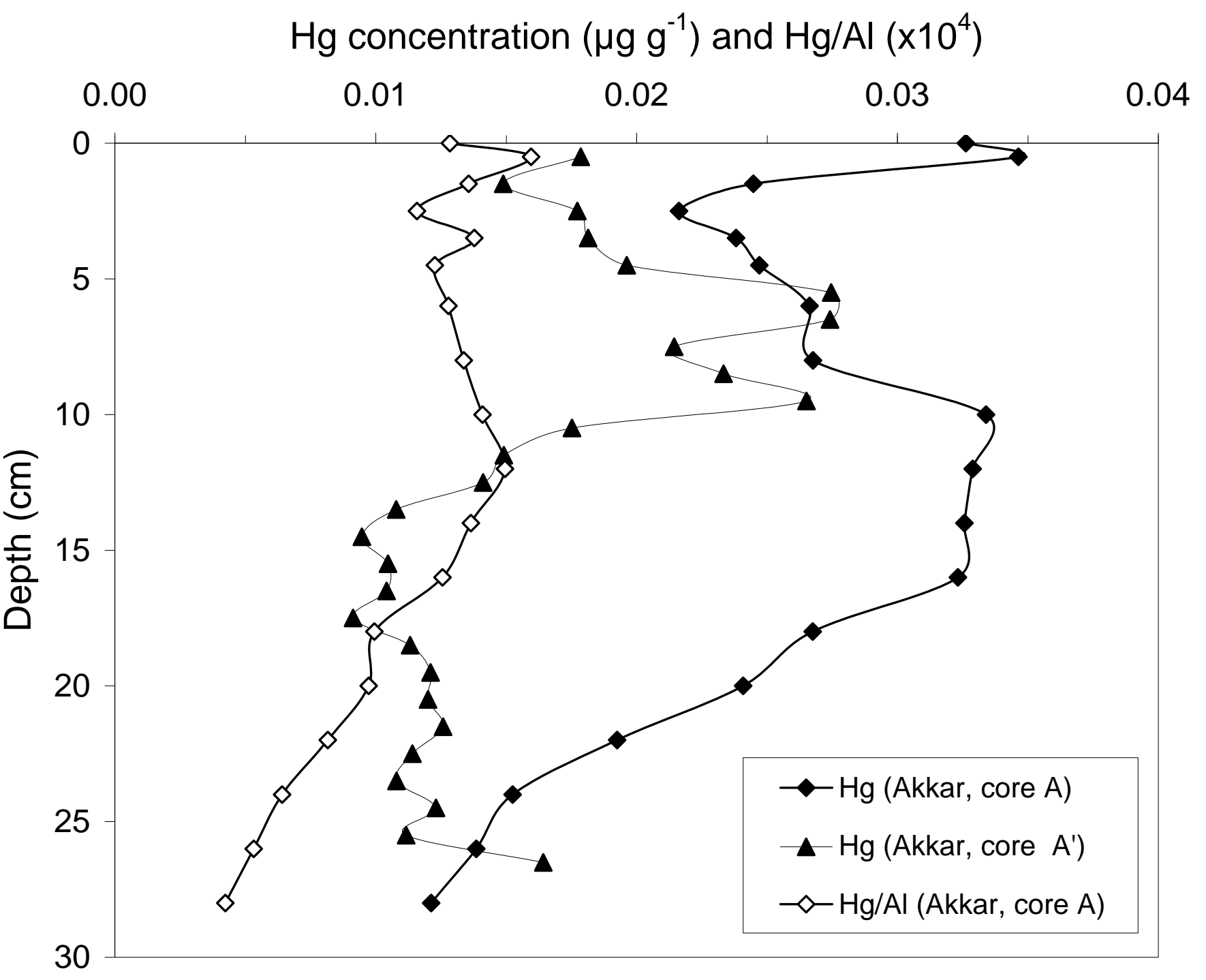


Figure 3b

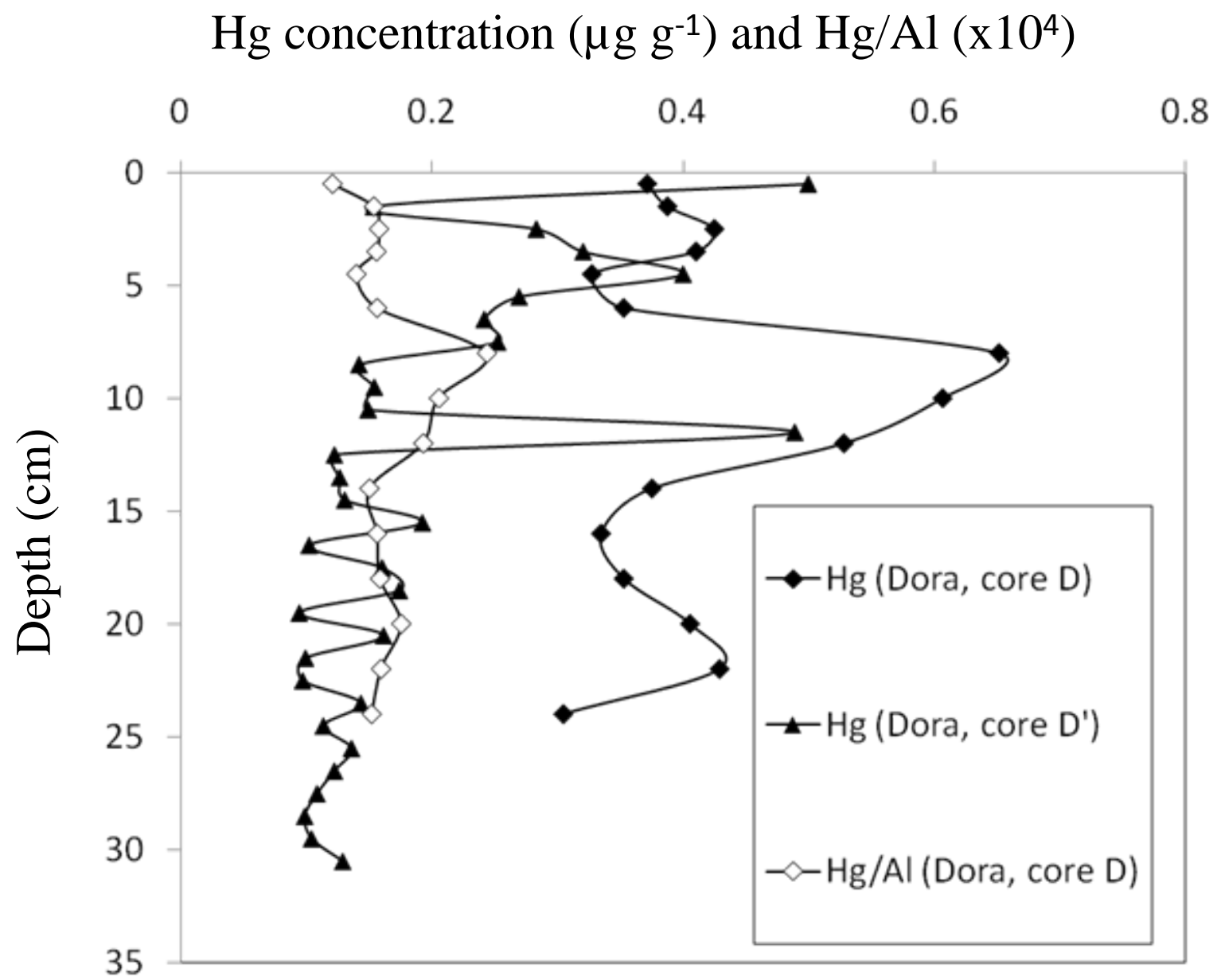


Figure 3c

$\mathrm{Hg}$ concentration $\left(\mu \mathrm{g} \mathrm{g}^{-1}\right)$ and $\mathrm{Hg} / \mathrm{Al}\left(\times 10^{4}\right)$

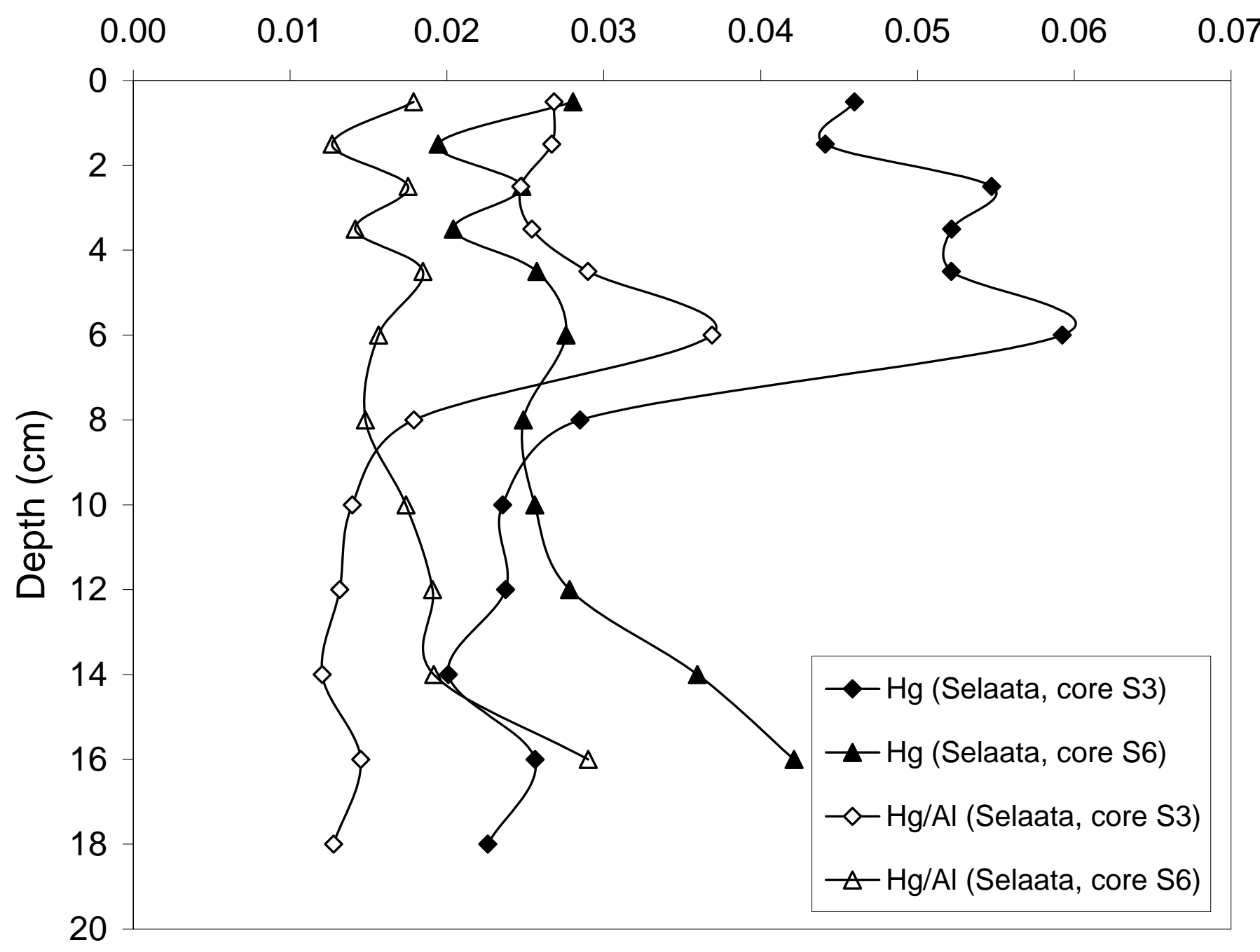




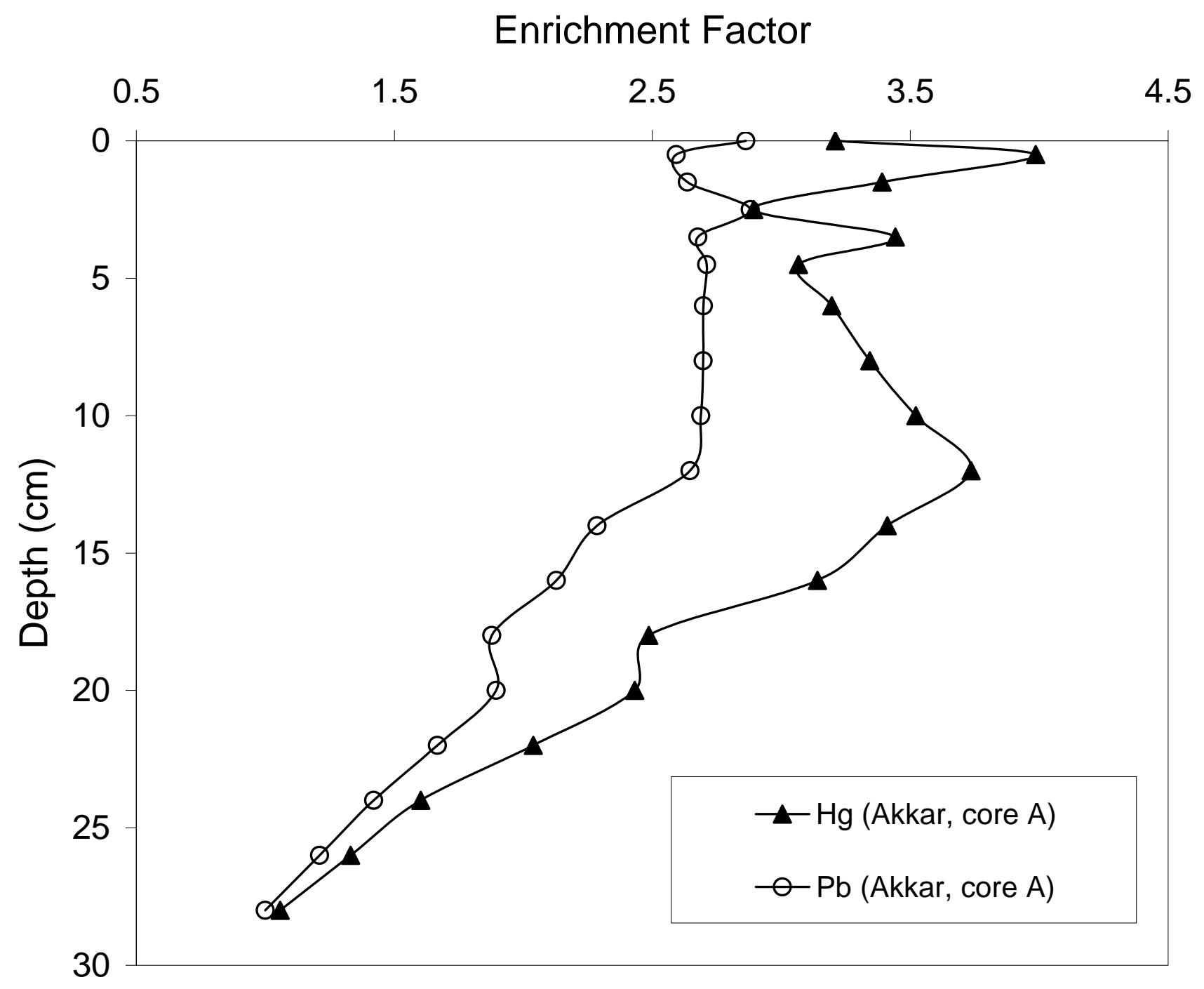


Figure 5. Vertical profiles of particulate methylmercury in Akkar (A') and Dora (D') sediments

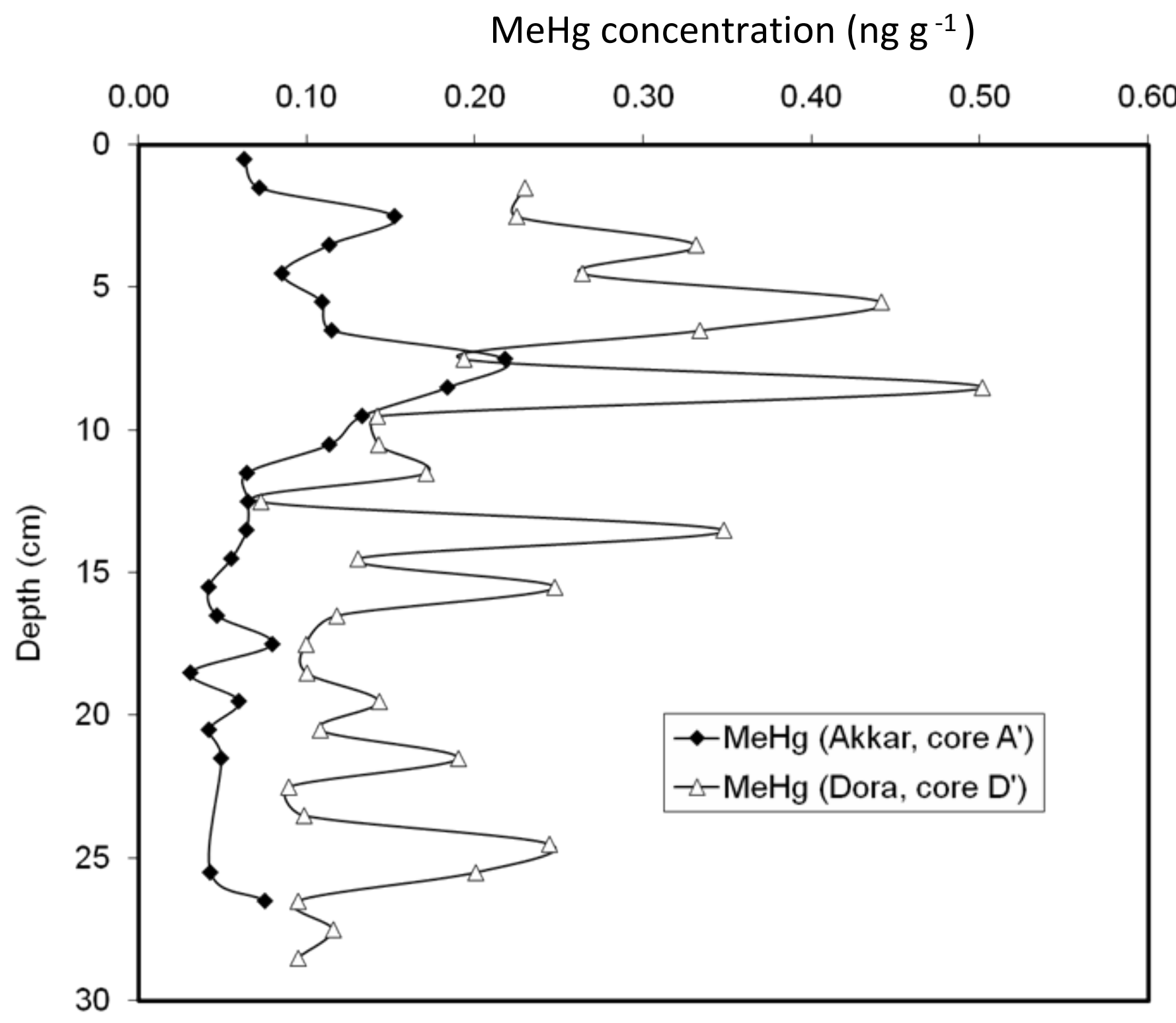


Figure 6. Vertical profiles of dissolved methylmercury in deep layers of the water column and in sediments pore waters of Dora and Selaata sites.

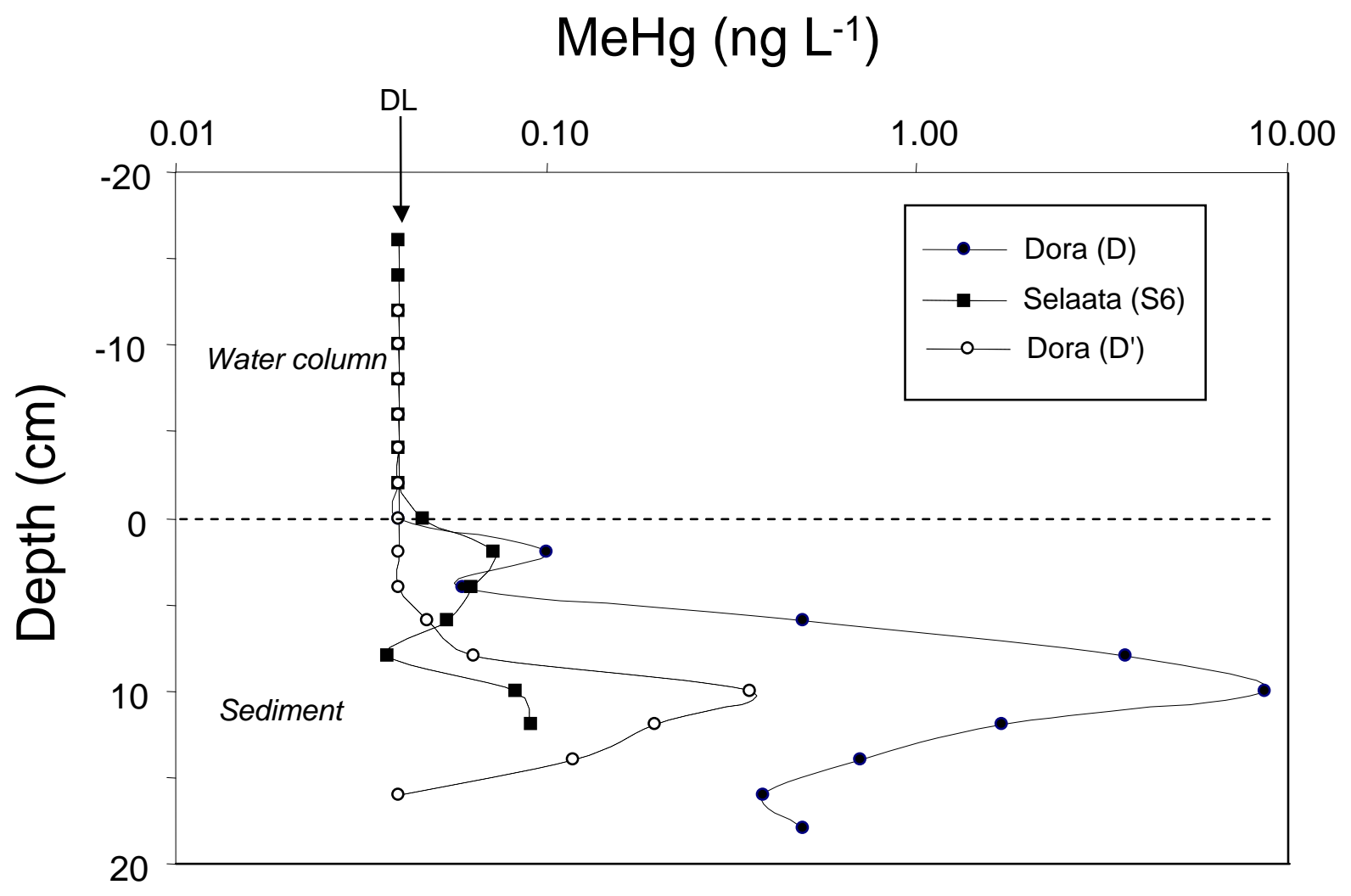

